\title{
Stage III Thyroid Gland Follicular Carcinoma AJCC v7
}

National Cancer Institute

\section{Source}

National Cancer Institute. Stage III Thyroid Gland Follicular Carcinoma A/CC v7. NCI

Thesaurus. Code C9121.

Stage III includes: (T3, N0, M0); (T1, N1a, M0); (T2, N1a, M0); (T3, N1a, M0). T3: Tumor greater than $4 \mathrm{~cm}$ in greatest dimension and limited to the thyroid gland, or tumor of any size with minimal extrathyroid extension (e.g., extension to sternothyroid muscle or perithyroid soft tissues). T1: Tumor size $2 \mathrm{~cm}$ or less in greatest dimension, limited to the thyroid gland. T2: T umor more than $2 \mathrm{~cm}$ but not more than $4 \mathrm{~cm}$ in greatest dimension, limited to the thyroid gland. N0: No regional lymph node metastasis. N1a: Metastasis to pretracheal, paratracheal or prelaryngeal/Delphian lymph nodes (Level VI lymph nodes). M0: No distant metastasis. (AJCC 7th ed.) 